IZA DP No. 5135

Does More Money Make You Fat? The Effects of Quasi-Experimental Income Transfers on Adolescent and Young Adult Obesity

Randall Akee

Emilia Simeonova

William Copeland
Adrian Angold

E. Jane Costello

August 2010 


\title{
Does More Money Make You Fat? \\ The Effects of Quasi-Experimental \\ Income Transfers on Adolescent and \\ Young Adult Obesity
}

\author{
Randall Akee \\ Tufts University and IZA
}

Emilia Simeonova

Tufts University

William Copeland

Duke University

Adrian Angold

Duke University

E. Jane Costello

Duke University

Discussion Paper No. 5135

August 2010

IZA

P.O. Box 7240

53072 Bonn

Germany

Phone: +49-228-3894-0

Fax: +49-228-3894-180

E-mail: iza@iza.org

Any opinions expressed here are those of the author(s) and not those of IZA. Research published in this series may include views on policy, but the institute itself takes no institutional policy positions.

The Institute for the Study of Labor (IZA) in Bonn is a local and virtual international research center and a place of communication between science, politics and business. IZA is an independent nonprofit organization supported by Deutsche Post Foundation. The center is associated with the University of Bonn and offers a stimulating research environment through its international network, workshops and conferences, data service, project support, research visits and doctoral program. IZA engages in (i) original and internationally competitive research in all fields of labor economics, (ii) development of policy concepts, and (iii) dissemination of research results and concepts to the interested public.

IZA Discussion Papers often represent preliminary work and are circulated to encourage discussion. Citation of such a paper should account for its provisional character. A revised version may be available directly from the author. 


\section{ABSTRACT \\ Does More Money Make You Fat? The Effects of Quasi-Experimental Income Transfers on Adolescent and Young Adult Obesity ${ }^{*}$}

This paper examines how exogenous income transfers during adolescence affect contemporaneous body mass index (BMI) measures and young adult obesity rates using evidence from the Great Smoky Mountains Study of Youth. The effects of extra income differ depending on the households' initial socio-economic status, tracing out an inverted U-shaped relationship between initial income and BMI. Youths who resided in families that had high pre-treatment annual incomes experience no change in young adult obesity rates as a result of the income transfers, while the BMI of poorer children increases. Part of this effect is due to differential increases in height, as well as weight. An exogenous annual transfer of $\$ 4,000$ per adult family member results in an almost $4 \mathrm{~cm}$ gain in height-for-age. Adolescents coming from worse-off households experience an increase in weight only, without the corresponding change in height. The cumulative effects of the increase in household income persist for several years into young adulthood.

JEL Classification: I10, I12, I38

Keywords: $\quad$ obesity, health, cash transfer, adolescents, indigenous peoples

Corresponding author:

Randall Akee

Economics Department

Tufts University

8 Upper Campus Road

Braker Hall

Medford, MA 02155

USA

E-mail: randall.akee@tufts.edu

\footnotetext{
* The authors would like to thank Sally Kwak, Albert Ma and the participants at the UC Riverside Department of Economics Applied Economics Seminar and the IIES, Stockholm University for helpful discussions. Any errors, omissions or oversights are ours alone.
} 


\section{Introduction}

Since the late 1980s, the US has experienced a drastic increase in the prevalence of childhood and adolescent obesity. According to the most recent National Health and Nutrition Examination Survey (2008) 11.9 percent of children aged 2-19 were at or above the 97th percentile of the BMI-for-age growth charts and 17 percent were at or above the $95^{\text {th }}$ percentile (Ogden et al, 2010).

The upward trend in obesity rates is steepest among poor children, reaching up to 20 per cent in some social groups (Anderson, Butcher, and Schanzenbach, 2007). Comparisons among different racial and ethnic groups within the US show that the incidence of obesity is highest among Native American children. A recent study found that 31 per cent of American Indian/Native Alaskan 4-year olds are obese (Anderson and Whitaker, 2009). Childhood obesity is highly predictive of later-life morbidity, implying that health problems such as diabetes and cardio-vascular diseases will persist at elevated levels for the Native American population, unless policy interventions reverse current trends.

The poor have been hit particularly hard by the obesity epidemic, but the direction of causality between income and body mass is unclear. Do higher earnings contribute to slimmer bodies or are slender people likely to earn more ${ }^{1}$ The identification problem is less severe if one considers children's outcomes, since children in the US do not work full-time and are dependent on their parents. But children's outcomes may be strongly correlated with those of other household members. For example, a number of correlational studies have shown that overweight mothers are more likely to have overweight children. ${ }^{2}$

\footnotetext{
${ }^{1}$ There is research suggesting that this may be the case. Hamermesh and Biddle (1994) find that attractive people tend to earn more than their plain counterparts. They also find that attractive people sort into occupations where rewards for good looks are highest.

${ }^{2}$ E.g. Malrid et al, 2004, Danielzik et al, 2004, Nguyen et al, 1996
} 
The main contribution of this paper is to overcome the income-body mass endogeneity problem. We use quasi-experimental evidence from a government transfer program which exogenously increased incomes for one group of children while leaving the comparison group unaffected. Moreover, we are able to compare the outcomes of children across age cohorts who were affected for different lengths of time. The government transfer is a per capita disbursement to adult members of an American Indian tribe; non-Indians in the community do not receive these disbursements. Because the exogenous income transfers depend only on American Indian origins and we are able to control for differences across the two ethnic groups by using within-cohort and within-child comparisons, we identify a causal relationship between extra household income and the BMI of adolescents. We examine the effect of the transfer payment (derived from casino profits on the American Indian reservation) on BMI, weight and height at different points in the adolescent's development. To trace out the differential impacts of extra income depending on initial conditions, we estimate income-BMI, income-weight and income-height profiles for adolescents coming from households of different pre-transfer income categories.

Theory predicts an inverted U-shape relationship between income and weight (Lakdawalla and Philipson, 2002). The inverted U-shape results from a restriction in calories due to an income constraint at the very lowest levels of household socio-economic status (SES). As income increases, households and individuals increase their consumption of food and consequently we expect to see an increase in weight. Beyond a certain threshold, the wealthiest households are either able to purchase higher quality foods that are more nutritious or pursue health-related activities, so the income-weight curve starts sloping downwards. To our knowledge, there is no experimental evidence testing this prediction. This study confirms the non-linearity of the relationship using exogenous changes in unearned income. We find evidence that extra unearned income increases BMI among youths from poorer households. 
At the same time, we find a significant reduction in obesity rates among children in wealthier households. The children who are affected by the government transfer program for the longest amount of time experience the strongest effects.

The transfer increased BMI among children from families with average incomes below $\$ 40,000$, but not among their better off peers. Further investigation reveals that this is due to differential changes in weight and height among youths coming from different economic backgrounds. We find evidence for a "BMI Kuznets curve", which traces out the effects of extra unearned income on adolescent obesity. Children from initially poorer households increase their BMI over time as a result of the income transfer. Relative to the highest household income category of $\$ 50,000$ and over, the effect steadily increases by initial household income category to a maximum at $\$ 20,000$ - $\$ 30,000$ and diminishes thereafter. These results imply that growing up in a poor household has long-lasting effects on adolescent health that cannot be immediately overcome by extra income transfers.

Decomposing the effects by weight, we find that adolescents from households that receive the transfer payment and have initial incomes below $\$ 35,000$ experience weight gain relative to their initially wealthier counterparts. We also find that the beneficial effects of the transfer payments on height are restricted to the highest bracket of the initial income distribution; individuals from poorer households do not grow as much as their initially wealthier counterparts. The two most likely explanations are that the extra income transfers allow better-off households to make better nutrition choices or that the quality and amount of physical exercise undertaken by the children is improved. While we are constrained by data availability on nutrition choices, we offer some evidence against the second hypothesis.

The next section puts the present study in the context of the current literature on obesity. Section 3 describes the data and the empirical strategy. Next, we discuss the results 
and some of the potential mechanisms. In Section 5 we offer some robustness checks and comment on alternative hypotheses. Section 6 offers some concluding remarks.

\section{Background}

When studying the determinants of childhood obesity in developed economies, economists have concentrated primarily on the effects of the supply and quality of food consumed by children. This research is highly relevant for public policy aimed at reducing adolescent obesity rates. For example, it has been shown that fast food restaurants close to school grounds increase the prevalence of obesity among $9^{\text {th }}$ graders (Currie et al, 2009) and higher prices for fruit and vegetables in the neighborhood are associated with higher BMI, especially among economically disadvantaged children (Powell and Chaloupka, 2009). Increased supply of fast food or "bad" food potentially available to children contributes to higher incidence of childhood obesity.

However, studies investigating the effects of changing access to different types of food assume that the demand-side effects are negligible. In this study we ask the opposite question: barring any significant increases in the supply of different types of nutrients, would higher household incomes cause changes in obesity rates among youths? Even if policy regulates the supply of fast food to remain at current levels, how would the growth in disposable income affect children’s BMI? Our identification strategy allows us to control for changes in the supply of nutrients to a geographic area and isolate an effect that is purely due to exogenous changes in households' disposable income.

One way to assess the contribution of increased incomes on adolescents' BMI is to consider exogenous changes in the affordability of different types of food. Affordability can increase in two ways: by providing extra funds that can be spent on food only (such as food stamps and other coupons) and by changes in expendable income. Previous studies have 
found mixed results on the effect of food stamps on adult obesity rates (Townsend et al, 2001, Chen et al, 2005; Kaushal, 2007). Two recent studies examine the causal effects of extra expendable income on BMI. Schmeiser (2008) considers low income women while Cawley et al (forthcoming) study Social Security recipients. Both utilize instrumental variable (IV) strategies to estimate changes in BMI and obesity rates attributable to changes in income. Our study differs in that we focus on children and have a quasi-experimental framework; in addition we also capture the entire distribution of initial socio-economic conditions and can estimate the effects of extra income on a more diverse set of households. We are not aware of any previous economics research on the effects of exogenously increased household income on adolescents’ BMI in the United States. ${ }^{3}$

Empirically, the relationship between income and obesity is hard to identify. Among studies using data on adult populations, the main problem is identifying the direction of causation - higher incomes make food more accessible, but obesity and the associated health problems make it harder to earn high incomes. People with higher incomes can afford better food, and they are also less likely to be obese. ${ }^{4}$ There is a separate literature estimating the effect of BMI on earnings (Kline and Tobias, 2008; Cawley, 2004; Mocan and Tekin, 2009) and at least one study shows that overweight and obese adults are likely to suffer from low self-esteem which may be underlying their lower earnings (Mocan and Tekin, 2009). To plausibly capture the empirical relationship between income and weight, one has to

\footnotetext{
${ }^{3}$ In a study examining obesity rates for adults over thirty years, Chang et al (2005) find that there has been an increase at all levels. Their study differs from ours in that they are looking at an association between income and obesity (they do not have an exogenous change to income) and they are looking at adults only. Halliday and Kwak (2009) examine the correlation between children and their peers’ BMI in a nationally representative dataset. This research does not examine the role of income on the adolescents’ BMI, however.

${ }^{4}$ Behrman and Deolalikar (1987) have shown that changes in income in a developing country are not necessarily associated with changes in food consumption - they find that it depends on the income elasticity of food.
} 
exogenously increase the amount of dispensable income available to the household without affecting the extent of physical activity or physical attractiveness needed to earn that income.

Assessing the effect of exogenous income transfers on the BMI of children and adolescents is attractive for two reasons. First, the transfers we consider in this paper come from an exogenous source and their size is not affected by the initial financial situation of the household. Second, the exogenous income transfer affects children while they are teenagers a time when most children earn little on their $\mathrm{own}^{5}$. The children in our study are subjected to the income effect, but unlikely to be affected by a substitution effect away from labor. In developing countries, the case would be quite different in that the additional household income would allow children to work less and enter school which may have separate effects on the child's BMI. ${ }^{6}$

We find that extra income increases height as well as weight in children coming from initially better-off households. There are several growth spurts in children's physical development, during which they gain significantly in height. For example boys in the US gain up to $10 \mathrm{~cm} /$ year at age 13, and up to $5 \mathrm{~cm} /$ year at ages 14-16 (see, e.g. Figure 1 in Case and Paxson, 2008). Even though environmental factors during childhood are thought to contribute only $20 \%$ of height differences between adults (see Silventoinen, 2003 for a review of the literature), there is evidence that children catch up with their better-off peers if exposed to better conditions at some point during their growth path. ${ }^{7}$ In our study, the youngest treated

\footnotetext{
${ }^{5}$ Child labor laws and mandatory schooling requirements in the U.S. prevent children from working full time until age 18.

${ }^{6}$ See, for instance, the literature on child labor in developing countries. Edmonds (2008) provides a useful overview of the findings.

${ }^{7}$ For example, African-American children in the US displayed a large increase in height after the age of 10 (when they typically entered work in the era of slavery) presumably because they started to receive more food while working. Their ultimate adult height was only 1-2 cm shorter than contemporaneous Union Army troops
} 
cohort were aged thirteen at the time that the income transfers were first received by the parents. On average, these children would have gained around $25 \mathrm{~cm}$ (girls) and $28 \mathrm{~cm}$ (boys) in height between their $13^{\text {th }}$ and $20^{\text {th }}$ year. Our estimates imply an additional height increase of about $13 \%-15 \%$ attributable to the extra income isolated among children coming from the best-off households. We find this estimate plausible in light of the previous literature on nutrition and adolescent height.

This paper confirms that the relationship between household income and adolescents' body mass is non-linear; it actually resembles a Kuznets curve. Moreover, we find that children coming from households earning $\$ 40,000$ or more experience no change in their BMI following the income transfer. Our results show that the turning point between increasing and decreasing BMI as a function of extra unearned income is somewhere around the $\$ 30,000$ initial household income level.

We were concerned that the extra income would alter maternal labor force participation among Native Americans which would then, in turn, affect the child's obesity levels into adolescence and young adulthood. We do not find any evidence for this in our data. An additional concern was that the observed improvement (Akee at al, 2010) in the child's own educational attainment may play a role in reducing their obesity levels. Although we find that the probability of graduating from high school and the number of years of education increase for adolescents affected by the transfers, these effects are isolated to Native American children coming from households previously in poverty and we find no or positive effects on obesity rates in this group. Therefore, we conclude that improvements in own education do not immediately transfer into improved BMI. We have also included an naturalized Swedes who immigrated to Sweden as children. 
explicit control variable for completing high school in the estimations and this does not affect our results.

We also test whether initial health conditions such as weight at birth affect adolescent obesity rates. On average, children who were born with low birth weight $(<2500$ grams at birth) are less likely to be obese, and those born of high birth weight ( $>4500$ grams) are more likely to be obese at age 19 than the omitted category (normal birth weight, between 2500 and 4500 grams). These effects disappear by age 21. Including birth weight as a control variable does not alter the coefficient estimates of the effect of extra income. We also consider the hypothesis that the income-BMI relationship we estimate is due to the restricted supply of nutrients in poorer areas, which precludes low-income families from buying better food. Including county fixed effects that absorb unobserved heterogeneity between neighborhoods does not significantly affect the results. We interpret this as evidence that household consumption choices, rather than the supply of food and amenities, are the driving force behind our findings.

Finally, the child's (or the child's representative's) bargaining power within the household is likely to be different depending on whether there are biologically non-related members who may benefit from the extra income. Previous research in both developed and developing countries has shown that exogenous changes to household income can have different effects on children's welfare depending upon who receives the income (Duflo, 2003; Duflo and Udry, 2003; Duncan 1990 and 1994; Lundberg et al, 1997). Specifically, these researchers find that additional unearned household income that accrues to the female parent (mothers or female guardians) tends to increase spending on children and joint household consumption goods as compared to when income accrues to the male parent. We find no differences in children's outcomes depending on which biological parent - the mother or the father - receives the extra income. 


\section{Data and empirical strategy}

The Great Smoky Mountains Study of Youth (GSMS) is a longitudinal survey of 1420 children aged 9, 11 and 13 years at the survey intake that were recruited from 11 counties in western North Carolina. The children were selected from a population of approximately 20,000 school-aged children using an accelerated cohort design. ${ }^{8}$ American Indian children from the Eastern Band of Cherokee Indians were over sampled for this data collection effort Survey weights are used in the child outcome regressions that follow. The federal reservation is situated in two of the 11 counties within the study. The initial survey contained 350 Indian children and 1070 non-Indian children. Proportional weights were assigned according to the probability of selection into the study; therefore, the data is representative of the school-aged population of children in this region. Attrition and nonresponse rates were found to be equal across ethnic and income groups.

The survey began in 1993 and has followed these three cohorts of children annually up to the age of 16 and then re-interviewed them at ages 19 and $21 .^{9}$ Additional survey waves are scheduled for these children when they turn 25 and 26 years old. Both parents and children were interviewed separately up until the child was 16 years old; interviews after that were only conducted with the child alone.

After the fourth wave of the study, a casino was opened on the Eastern Cherokee reservation; the survey children were approximately 13, 15 and 17 years of age at that time.

\footnotetext{
${ }^{8}$ See Costello E. Jane, Adrian Angold, and Barbara Burns, and Dalene Stangl, and Dan L. Tweed, and Alaatin Erkanli, and Carol M. Worthman (1996) for a thorough description of the original survey methodology.

${ }^{9}$ Individuals are interviewed regardless of where they are living (whether on their own, in college, or still living with their parents). No child is dropped from the survey because they moved out of their parent's home. We find no statistically significant difference in selection between the treatment and control groups. American Indians comprise $24 \%$ of the sample in the very first survey wave and comprise approximately $27 \%$ of the sample at age 21.
} 
The casino is owned and operated by the tribal government. A portion of the profits are distributed on a per capita basis to all adult tribal members. ${ }^{10}$ Disbursements are made every six months and have occurred since 1996. The average annual amount per person has been approximately $\$ 4000$. This income is subject to the federal income tax requirements.

The outcome variables of interest are Body Mass Index (BMI), height, weight and obesity. The first three measures are recorded at each survey wave. Interviewers measured survey respondents using rulers and scales. Medically recommended levels of BMI are between 20 and 25 for adults. Individuals with BMI levels of 25-30 are considered overweight in adults; those with BMI greater than 30 are considered obese. In the analysis we drop several extreme outliers (which we attribute to either recording error or measurement error) for recorded BMI levels that exceed 100 or are below 10. We have constructed a simple obesity index variable for our survey subjects (ages 19 and 21) which takes on the value of 1 when BMI is greater than 30 and is 0 otherwise. Similarly, we create an overweight (or more) variable which takes on the value of 1 if they have a BMI of 25 or higher and 0 otherwise. For adolescents, we utilize the Centers for Disease Control BMI-for-age chart for boys and girls. These measures account for differential growth rates between the genders at different ages. Adolescents are classified by age, gender, weight and height and assigned a percentile. Individuals that exceed the 95th percentile for their age and gender group are considered obese while individuals who are above the 85th percentile are classified as overweight (inclusive of the obese). We employ these designations in the tables that follow.

\footnotetext{
10 All adult tribal members received these per capita disbursements. If there were any non-compliers (American Indian parents that either did not receive or refused the additional income) then any estimates found here would be an under estimate of the true effects of additional income. All enrolled, American Indian children were eligible for the casino disbursements themselves at age 18 if they completed high school; even if they did not complete high school they would receive the casino transfers at age 21 . While they initially did not know exactly how much the transfers will amount to, tribal members had every reason to believe that this was a permanent positive change in their incomes.
} 
Table 1 provides descriptive statistics. The sample is balanced on conditions at intake such as age, sex, and maternal labor force participation between American Indians and the rest. American Indian mothers are significantly less likely to have been to college, and more likely to have completed high school. Native Americans are significantly less likely to be of low birth weight (4.6\% vs $6.5 \%$ in whites), but equally likely to be of high birth weight (over 4500 grams). The incidence of obesity and being overweight is substantially higher among American Indian youth. The majority of these adolescents are overweight (65\%) as compared to $39 \%$ of the rest of the sample. The difference comes from a ten-kilogram difference in weight, while average height is very similar between the two groups. American Indians also come from poorer families - on average, their households received ten thousand dollars less in annual income in the three survey waves before the casino opened; household income is provided in categories and a value of 6 corresponds to approximately $\$ 30,000$ (the average for non-Indians) while a value of 4 corresponds to an annual income of approximately $\$ 20,000$ (the average for American Indian households). The casino disbursements (approximately \$4,000) represent more than a ten percent increase in the average household income of parent couples of mixed heritage, and more than 20 percent increase in households of two American Indian parents. The casino transfers alone would be enough to close the income gap between an average family with two white parents and families composed to two Native American parents.

In Figure 1 we show a basic illustration of the changes in BMI attributable to the exogenous income transfers. In these figures we hold the age of all three cohorts constant at 19 years for comparability; Panel A considers American Indians and Panel B considers the non-Indian children. The solid line in Panel A traces out the distribution of BMI in the oldest cohort of American Indian children (who resided the shortest amount of time in households with increased household income), whom we consider a control group for the other two age 
cohorts as they were minors for only one year of treatment ${ }^{11}$. The long dashes illustrate the corresponding distribution for the middle age cohort (15 year-olds at the beginning of treatment); the dotted line shows the distribution among the youngest age cohort (13 year-olds at the beginning of the treatment), who spent the greatest amount of time in households that received the income transfers. While the entire distribution of BMI appears to be moving to the right with each new cohort, it is clear from the graphs that the prevalence of high levels of BMI (over 25) changed significantly for the second and third cohorts. Children whose parents received extra transfers are moving from healthy bodies to being overweight and obese. By comparison, the control group of non-American Indian adolescents, illustrated in Panel B, are not experiencing any significant changes in obesity prevalence between cohorts. The distribution plots offer strong initial evidence that the exogenous income transfers had an effect on BMI, that the effect was concentrated among the treated group of younger American Indian children, and that it resulted in a non-trivial change in the prevalence of obesity in American Indian youths.

\section{Empirical Estimation}

Difference-in-Difference Regressions

We compare young adult outcomes for adolescents that resided for a total of six (four years for the middle age cohort) years as minors in households with increased incomes to adolescents who resided for at most two years as minors in households with exogenously increased incomes. We employ a difference-in-difference methodology. This specification allows us to compare the effect of four additional years of higher household incomes on the incidence of obesity for these children. The two youngest age cohort variables (Age 9 and

\footnotetext{
${ }^{11}$ We consider adolescents minors up to age 18.
} 
Age 11 at survey intake; ages 13 and 15 at first treatment) function as the "after-treatment" cases and the oldest age cohort (Age 13 at survey intake; age 17 at first treatment) functions as the "before-treatment" case. We focus explicitly on the effect of the per capita transfer on the incidence of obesity.

An examination of the effect of the treatment on household income indicates that almost all of the additional cash transfer shows up as additional household income in each survey wave. ${ }^{12}$ The size of the exogenous increase in household incomes can take on two different values depending upon the number of American Indian parents in each household. It is possible for there to be 0,1 or 2 American Indian parents in each household. Clearly households with two American Indian parents will have double the amount of exogenous income than households with only a single American Indian parent. Households without an American Indian parent serve as control households. We treat the number of parents as a continuous variable and we therefore have two interaction variables which are of interest. The equation below details the specification:

$$
\begin{aligned}
& Y_{i}=\alpha+\beta_{1} \times \text { Age }_{i}+\beta_{2} \times \text { Age } 1_{i}+\delta_{1} \times \text { NumParents }+\gamma_{1} \times \text { Age } \times \text { NumParents }_{i}+ \\
& \gamma_{2} \times{\text { Age } 1_{i} \times \text { NumParents }}_{i}+X_{i}^{\prime} \theta+\varepsilon_{i}
\end{aligned}
$$

In the equation above, $\mathrm{Y}$ is the incidence of obesity for the survey children at ages 19 or 21 in young adulthood. In the equation above, the Age9 and Age11 variables indicate whether or not the child is drawn from the initially age 9 or age 11 cohorts respectively -- the age 13 cohort is the omitted category in this regression. The variable NumParents indicates the number of American Indian parents in that child's household. The two coefficients of interest

\footnotetext{
12 We find that the effect of the treatment (household eligibility for the casino per capita transfer) results in approximately \$3900 additional household income at each survey wave. The average amount distributed per person has been about $\$ 4000$ per year. This suggests that households do not alter their labor participation in response to this additional household income.
} 
for this research are $\gamma_{1}$ and $\gamma_{2}$, which measure the effect of receiving the casino disbursements and being in either the age 9 or age 11 cohorts relative to the 13 year old cohort. The vector $\mathrm{X}$ controls household conditions prior to the opening of the casino and includes average household income over the four years, the sex of the child, the race of the child, mother's labor force participation and education level of the mother. We estimate (1) using probit models as our outcomes are binary. The probit coefficients are hard to interpret, hence in the estimation tables we report marginal effects estimated after a probit regression.

Identification of equation 1 relies on the fact that the different age cohorts of children were randomly sampled within American Indian and non-Indian groupings. The next section provides evidence for this and also indicates that the two groups of households (American Indian and non-Indian) faced similar conditions in the labor market and with regard to social conditions. $^{13}$ It is also important to note that there were no new health or educational programs which were created immediately after the advent of casino disbursements by the tribal government. This is important in establishing the fact that time variant characteristics that were related only to American Indians (such as tribally-funded health and nutrition programs) are not the causal factor here. In later years new programs have been developed, but for the crucial period in which these children were minors in their parents' households, there is little evidence of new programs. Anecdotal evidence suggests that the revenues from the casino operations were, at least in the short run, spent only on per capita disbursements to the tribally-enrolled membership. Spending on large scale construction was not initiated until 2001, when the youngest cohort was around 17 years old. Therefore, the children in this study were not minors when these new programs and facilities were operational.

\footnotetext{
${ }^{13}$ See Appendix Figures 1, 2 and 3, which provide the pre-casino trends for the American Indian and non-Indian children with regard to BMI, height and weight.
} 
Finally, we use global positioning system data (GPS) to compute a distance measure which serves as proxy for other non-cash transfer related effects of the casino operations on households. The average household is 32 miles (median is 36 miles) away from the casino, with a minimum distance of 5 miles and a maximum distance of 75 miles. We find that inclusion of this measure (which is available for all survey households) and an interaction variable with treatment households does not diminish the effects reported in later tables. ${ }^{14}$

\section{Fixed-Effects Panel Regression}

Given the panel nature of the data, we are able to examine the effect of a casino transfer payment on health inputs at each survey wave for the children in the survey. We examine changes in the body mass index of children (BMI), as well as their weight and height measures directly. Therefore, we employ a fixed effects regression for these three health outcome variables. The regression is given of the form:

$Y_{i t}=\alpha_{i}+X_{i t}^{\prime} \beta+\varepsilon_{i t}(2)$

In this regression, $\alpha_{i}$ is the individual fixed effect and $\mathrm{X}$ is the vector of control variables, including whether the individual child, i, belongs to a household that is eligible for casino payments. This indicator variable is always zero for households without American Indian parents; for households with American Indian parents the variable is zero for the first four survey waves and then takes the value of one thereafter.

\footnotetext{
${ }^{14}$ We include a measure of distance from each household to the casino (using Global Position System data) in level and interacted with household eligibility for casino payments in the Appendix Table 1. One can think of this distance measure as a proxy for the other non-cash transfer effects of the casino on households. The results for this regression indicate that the proximity to the casino does not statistically affect obesity
} 
Because the extra income was received by American Indian parents only, a potential concern is that the estimates from (2) could be driven by differences in growth path of height, weight, and BMI between American Indian children and the control group. For example, if American Indian children “caught up” with their peers after age 13, then some of the effect we attribute to extra income could actually be due to natural differences in physiology between the two groups. To test for the validity of this concern, we compare the growth paths of height, weight, and BMI between children of the oldest cohort, who were not affected by the income transfer until age 17. From previous survey waves, we have those children's measurements from age 13 onwards, which coincides with the age at which the youngest group of American Indian youths was first treated with the extra funds. We find no significant differences (or evidence of catch-up), in the growth paths of the two ethnic groups (see Appendix for the relevant figures).

\section{Results}

We first present results from the difference-in-differences models (equation 1) comparing outcomes between children of different cohorts and ethnic origins in adulthood. We then turn to the panel level regressions (equation 2) which show the effects of additional household income at each survey wave.

\section{$\underline{\text { Obesity rates }}$}

Table 2 shows the results from difference-in-differences specification comparing children at ages 19 and 21. The oldest age cohort (age 13 at survey intake; age 17 at beginning of treatment) of children comprises the omitted category.

Table 2 reports estimates from 3 regression models for youths at ages 19 and 21 .

Columns 1 and 4 show the difference-in-difference regressions based on the model in 
equation 1 . The coefficients of interest, while not statistically significant in these two regressions, indicate that adolescents who reside in households with at least one American Indian parent and in the youngest age cohort are less likely to be obese by ages 19 and $21 .{ }^{15}$ The interaction term for the second age cohort (age 11 at survey intake; age 15 at first treatment) is slightly positive, but it is also not statistically significant.

The other covariates in these regressions are also informative in determining obesity. We find that American Indian adolescents are between 33 and 42 percentage points more likely to be obese than non-Indians. Comparing estimates for the same cohorts at age 19 and age 21, it appears that the correlation between American Indian race and obesity becomes stronger with time. Additionally, we find that the average of childhood household income (in the three years prior to the government transfer program) has a negative relationship with obesity levels at age 19, but the effect loses significance by age 21 .

It has been hypothesized that one of the confounders of the child obesity epidemic is that mothers spend more time out of the household. It has been shown elsewhere that the extra income did not reduce labor force participation for parents in this sample (Akee et al, 2010). We add controls for maternal labor force participation, and two levels of mother's educational attainment. The omitted education category is high-school drop-outs.

\footnotetext{
${ }^{15}$ We emphasize here that due to the structure of the survey data, we cannot distinguish differential effects by age at the beginning of treatment versus the duration of treatment. For example, the comparisons between cohorts 1 and 2 at age 19 capture both the fact that cohort 1 spent up to 6 years under treatment while cohort 2 spent only up to 4, in addition to the fact that cohort 1 began treatment at age 13 and cohort 2 began treatment at age 15. Comparing outcomes at ages 19 and 21 across the same cohort allows us to gauge the differential effect of 2 more years of treatment, conditional on starting the extra transfers at the same age and assuming that children continue to receive some of the transfer money after age 18 from their parents. The alternative explanation for differences in the coefficients is that the long-term effects of being exposed to exogenous income transfers at earlier age are larger than the medium-term effects. These differences in effects could operate through extra education or changes in the culture of nutrition. We discuss this possibility in more detail below. Comparing outcomes for the same cohort at different ages is the only way for us to make inferences about the effects of duration versus age at the start of treatment.
} 
Maternal high school education is insignificantly different from the omitted category, but mothers with college degrees are less likely to have obese children. We find marginally statistically significant negative coefficients for 21 year olds who have mothers with college degrees.

We further explore the results for the negative effect of initial household income in columns 2 and 5. In these regressions we interact initial household income with the original difference in difference term from columns 1 and 4 . We find significant coefficients on the triple difference term. Our results confirm that differences in initial household income tend to affect obesity for the household children later in life. At age 19, all the action is in the interaction term. There are no significant level effects of the exogenous increase in incomes across cohorts. But there are differential effects between youths in different parts of the income distribution. The results suggest that exogenous income transfers reduce the probability of obesity by $3 \%$ at 19 years of age with each $\$ 5,000$ increase in initial household income. The effects exist only for the youngest cohort of adolescents - youths who were first treated at the age of $13 .^{16}$

In column 5, for the 21 year olds we find that the triple difference term and the main effect of treatment are both statistically significant. The effect of extra household income on obesity is positive but decreasing with initial income. The part of the initial income distribution where the effect on obesity switches sign from positive to negative is around $\$ 35,000-\$ 40,000$ in initial annual household income. Above that level youths start experiencing a negative and increasing effect of extra income on obesity.

Columns 3 and 6 report the effects of extra income on the probability of being overweight (inclusive of being obese) for 19 and 21 year olds respectively; overweight is defined as having a BMI of 25 or higher. We find results that are qualitatively very similar to

\footnotetext{
${ }^{16}$ A placebo test for the effect of these age cohort and casino payment interactions on the children prior to the implementation of the transfer payments indicates no effect. These results are shown in Appendix Table 2.
} 
the coefficient estimates in the obesity specification for 21 year-olds; for 19 year olds, the effect of the government transfers on the probability of being overweight is significantly larger than the effect on the probability of being obese.

\section{Government Transfers, Parents and the Effect on Obesity}

Our initial results in Table 2 indicate that there is a long-run effect of the additional household income on the young adult obesity rates of recipients. In this section, we report whether the income effects differ according to who receives the income. Previous research in both developed and developing countries has shown that exogenous changes to household income controlled by an adult female can have beneficial effects on spending for children and household consumption goods (Duflo, 2003; Duflo and Udry, 2003; Duncan 1990 and 1994; Lundberg et al, 1997). These findings indicate that household bargaining power may dictate how additional income is spent. ${ }^{17}$ In analysis not reported here, we do not find any differential effect of casino payments by parental gender on adolescent obesity in our sample.

\section{$\underline{\text { Additional Controls }}$}

In the Appendix Table 3, we present additional results. Extra income transfers might directly affect the child's characteristics which in turn could affect their overweight. For example, using the same survey data Akee et al (2010) find that the income transfers improved high school attendance and completion rates particularly among children from economically disadvantaged households. Increases in own education may account for some of the observed effects on obesity. In Appendix Table 3 column 1 we report a specification

\footnotetext{
17 See Lundberg and Pollak (1996) for a discussion of this literature or Behrman (1997). Additionally, in a previous paper (Akee et al, 2010) we report that household structure appears to be unaffected by the casino income payments; we find no evidence for increased divorce or marriage rates over time.
} 
controlling for own high school completion at 21 . The results are very similar to the baseline specification reported in Table 2 except that the main effect of the extra income at age 21 becomes marginally statistically significant.

In column 2 of Appendix Table 3 we report a specification controlling for birth weight. This is the best proxy for initial health status, or the child's pre-treatment health capital, that we have. We split birth weight into three categories - low birth weight (below 2500 grams), normal weight ( $>2500$ and $<4500$ grams) and high birth weight ( $>4500$ grams). The omitted category in the estimation is normal birth weight. At age 21, there still is a significant negative effect of low birth weight on the probability of being obese.

The differences we find between youths coming from different income backgrounds could be due to nutrition supply, rather than demand effects. For example, if low-income households reside in areas where high quality food is sparse, children would receive worse nutrition even if parents have the financial means to provide better quality food. To test for such effects we include county-level fixed effects in our main regression. The results are reported in column 3 of Appendix Table 3. There are no significant changes in the main coefficients, suggesting that the effects we find are due to household demand choices rather than the availability of high quality food or amenities on the neighborhood level. Finally, in column 4 of Appendix Table 3 we include a measure of the individual's own income at age 21. Even though the coefficient is negative, it is not statistically significant. The main coefficient on the triple interaction term is not significantly changed.

\section{$\underline{\text { Panel level regression analysis }}$}

We examine the relationship between income and BMI - as well as income and height and weight directly - using changes over individual children's development. The panel estimations based on the model in equation (2) are reported in Tables 3-6. 
Adolescents residing in households eligible for casino transfer payments have on average an increase in BMI by one unit which is equal to $14 \%$ of the standard deviation of the mean BMI for American Indians. In column 2 of Table 3 we interact casino opening with five initial household income categories. The initial household income categories are the following: $\$ 0-\$ 10,000, \quad \$ 10,001-\$ 20,000, \quad \$ 20,001-\$ 30,000, \quad \$ 30,001-\$ 40,000, \quad \$ 40,001-$ $\$ 50,000$ and the omitted category is $\$ 50,001$ and higher. The effect of extra income on BMI shows that there is an increase in BMI that is increasing in magnitude up to the third household income category $(\$ 20,001-\$ 30,000)$. Extra household income still has a positive effect for the next two income categories, however the estimated coefficients are diminishing in both magnitude and statistical significance relative to individuals from households in the reference initial household income category. These results generally carry over to the specifications in columns (4) and (5) where we also control for non-linear effects of casino transfers on BMI.

In the model in column 3 we introduce an interaction term between casino and age to test for differential effect of casino disbursements with age. Confirming the findings from the DDD estimates from Table 2, the interaction term coefficient is negative. Receiving the income transfers later in life reduces the effect on BMI. In column 4 we show the estimates from a model including interaction terms with initial household income. ${ }^{18}$ The signs and relative size of the coefficients of interest remain similar across specifications.

Figure 2 plots the coefficients on the different income categories. The effects of extra income on BMI are clearly non-linear with respect to initial income levels. BMI increases by small but steady increments until income category four $(\$ 20,000)$, then starts slowly decreasing across the remaining initial household income categories.

\footnotetext{
${ }^{18}$ Additional specifications which includes age squared and further interactions do not change our main results and are not reported here.
} 
In all regressions we control for maternal labor force participation, which may have been affected by the income transfers. However, the effect is uniformly small and statistically insignificant, implying that the large effects reported in the difference-indifferences estimation are largely due to between-individuals differences. We include a dummy equal to one if there is a child younger than six in the household. Consistent with previous results in the development literature, the effects are negative and significant.

\section{Weight and height}

BMI has two components - weight and height; these components could be affected differentially by extra household income. We investigate whether the differences in BMI between adolescents residing in households from different parts of the income distribution could be caused by the differential impact of extra income on these two components. Table 4 reports the effect on the government transfer on adolescent weight. We find that there is a strong statistically significant effect of an increase in household income on weight gain. Being eligible for casino transfers increases children’s weight by 3.7 kilograms on average. In column 2 we interact the indicator of receipt of the government transfers with initial household income categories. The coefficients on the income category and government transfer payment interaction variables are increasing in magnitude and statistical significance up to category $4(\$ 30,001-\$ 40,000)$. The estimated coefficient on the next highest income category is smaller in magnitude and not statistically significant from the reference category. The pattern holds when we introduce age interactions in column 4 . In column 3 we test for differential effects of government transfers across ages, and obtain a significant and negative interaction coefficient. The shorter the period of exposure, the less likely it is that children will gain weight as a consequence of the transfers. Figure 3 provides the graphical depiction of these main results; specifically, weight increases across all initial household income 
categories until about $\$ 40,000$ after which the effects of extra income start to decrease in magnitude.

Similar to the results for weight, the effects of the government transfers on height also differ according to initial household incomes. In Table 5 we show that children who come from initially poorer families tend to have less height gain attributable to the extra income transfers than their initially wealthier peers. Column 1 indicates that the direct effect of the transfer payment has a positive effect on height, but it is not statistically significant. In column 2 we, once again, interact the government transfer payment with initial household income categories. We find that, compared to adolescents from the highest income category, almost all of the individuals from lower initial household income categories have less increases in height due to the extra transfers.

The negative interaction coefficient on casino transfers and age holds across all specifications. The effects of extra income are non-linear in age, as the main effects vary significantly after the inclusion of squares terms. This is intuitively plausible, as people tend to stop growing in height by their late teens. Figure 4 shows the trend of the effect of extra income across different levels of initial income.

Only adolescents from households with initial annual incomes above \$50,001 experience an increase in height; while only adolescents from households with initial household income less than $\$ 40,000$ experienced an increase in weight as a result of the transfer payments. This differential effect in height could be due to increased exercise or improved nutrition among financially better-off children. Unfortunately the GSMS survey does not include direct questions on either of these intermediate outcomes. Still, we are able to test whether children and parents report better relationships and parents report better supervision of children as a result of the income transfers. If parents are more involved in their children's everyday routine (e.g. they drive them to the pool/gym/stadium), that may be 
considered an indirect indicator for improved opportunities to exercise. Akee et al (2010) show that parent-child relationships improve with the income transfer, but in additional analysis (not reported, available from the authors) we find no differential impact depending on the initial levels of household income. We also included controls for the quality of the parent-child relationship in the height regressions reported in Table 5 and find no significant change in the initial income coefficients. We interpret this as circumstantial evidence that the extra income coming from the casino most likely "bought" different nutrition value for children in better-off families, rather than improved access to previously unavailable facilities.

In Table 6 we provide more evidence in fixed effects linear probability models of the probability of being obese, obese or overweight, and the probability that the young adult has gained weight in the last 3 months before the survey interview. The last measure is self-reported. We examine the effect across different income categories. The general pattern is similar to what we found for weight and BMI - the adolescent obesity Kuznets curve holds also in the panel specifications. The finding that having gained weight in the last 3 months is restricted to income levels below $\$ 50,000$ is particularly revealing. This suggests that changes in the body mass of adolescents induced by the extra income happen continuously over time.

In unreported analysis we tested whether the government transfers were significantly correlated with the probability that the respondent was on a diet or had any nutritional problems such as bulimia and anorexia. We found no evidence that the casino transfers resulted in differential eating behavior or eating disorders across treatment groups.

\section{Discussion of Household Income - Obesity Connection}

Rates of obesity among 12 to 19 year-olds in the US increased from $6.1 \%$ in 1970 to $15.5 \%$ in 2000 (American Obesity Association). Average BMI in 12-17 year-olds increased from 20.7 (in the early 1970s) to 22 (around 2000) in whites and from 20.3 to 23.7 
in blacks. Based on our estimates we can explain about $30 \%$ of the increase in adolescent BMI with rising incomes at the lower half of the income distribution (initial household incomes less \$50,000). ${ }^{19}$ By comparison, Schmeiser (2009) finds that increases in income explain between 23 and 29\% of the increase in obesity prevalence among 25-45 year-old low income women between 1990 and 2002. Cawley et al (forthcoming) report no significant changes in the BMI of elderly Social Security recipients that can be attributed to changes in Social Security income. Currie at al (forthcoming) explain $0.5 \%$ of the increase in obesity among ninth-graders since the 1970s by the increased availability of fast food. The empirical evidence to date suggests that effects of income increases on adolescent obesity are an order of magnitude larger than the contribution of increased fast food supply.

In the next couple of paragraphs we discuss some of the relevant literature on household consumption choices, assuming that the results we have found are mainly due to household-level decisions on nutrition. There are at least two ways in which extra income could affect children's nutrition intake. First, there may be differences in the proportions of extra income devoted to food consumption. Even though we are not able to trace families' consumption choices before and after the casino payments, there is enough evidence in the literature to suspect that consumption, and food consumption in particular, was affected in different ways by the casino transfers depending on the family's level of initial income. For example, Souleless (1999) shows that liquidity-constrained households are more likely to

\footnotetext{
${ }^{19}$ Based on simulations conducted by the authors using estimates of income mobility between 1970 and 2000 (as reported by the US Census 1970 and 2000) by \$5,000 income categories. In short, we estimate the proportion of households changing income categories across the income distribution between 1970 and 2000. We assign the corresponding increase in BMI (based on the results from our study, table 3) for each of these upwardly mobile households. We weight this increase by the proportion of households in the respective income groups to come up with our final estimate of how much increases in income have contributed to the change in the average BMI in 12-17 year-olds. We make the conservative assumption that a decrease in the number of households in a lower the next lowest income bin, .
} 
spend extra income on food and non-durables. He finds that total consumption increases by significantly less among poorer households following an exogenous income shock.

Second, the amount spent on food could be spent on different baskets of goods. The types of food that are bought with the extra income are also likely to differ depending on the family's finances. Reed et al (2005) estimate an array of own price and income elasticities for different types of foods. According to their results, demand for fruits and vegetables has the highest own price elasticity, while the demand for meats has the lowest. Home-cooked food is a gross complement with fruits and vegetables, dairy products, and cereals, but serves as a substitute for meats. On the contrary, food away from home is a gross substitute for all other types of foods except for meats. Dairy is the most income-elastic food class, followed by meats. Therefore, we expect that as households' incomes increase, families that react by increasing food spending are more likely to consume those foods. ${ }^{20}$ This may be one of the main factors behind our finding that casino payments increased the height of children from the highest income groups.

The findings in the study are relevant for the debate about the causes of the great increase in obesity rates in the US since the 1980s. We interpret this increase as partly due to changes in households' real income. It is implausible that food prices decreased for American Indians, but not for the rest of the sample population at the same time as the transfers began. The differential opening of fast food chains in territories more densely populated by American Indians is also an unlikely explanation, and we offer some evidence against it by controlling for distance to the casino and county fixed effects in sensitivity analyses. In earlier research, Akee et al (2010) find that the casino transfers did not induce changes in labor force

\footnotetext{
${ }^{20}$ Richards et al (2006) find, specifically for Native Americans, that the reduction in prices of carbohydrates over time may have resulted in an increase in spending (and consumption) on these relatively high calorie foods. The substitution away from protein rich food towards calorie-rich carbohydrates are driven primarily by differences in prices and may be an explanation for increased incidence of obesity in this community.
} 
participation of parents, even though we cannot rule out the hypothesis that patterns of food preparation may have changed as a result of the extra income (as suggested by Cutler at al, 2003). However, there must have been differential movement away from home-cooked and into pre-processed food across the initial income distribution for this explanation to be valid given our findings.

This study is informative to potential future policies intended to address the increasing obesity epidemic in the US. In developing countries, cash transfer programs are typically targeted at improving nutrition and child health. In Mexico, for instance, Hoddinott and Skoufias (2004) report that the Progressa program affected the quality of foods that people consumed; although this may also be due to changes in nutritional education programs. Providing poor US households with extra income would probably increase the BMI of household children; however, there may be detrimental long-run effects which affect the children's adolescent and adult obesity levels. There may be a need for educational and nutritional programs to assist in improving household consumption decisions that mitigate adolescent obesity.

\section{Concluding remarks}

Due to the quasi-experimental nature of our data, we are able to identify the effect of a permanent increase in household income on weight gain and eventual obesity in adolescents and young adults. We trace out differential effects of extra income depending on the initial financial conditions in the household.

We find that individuals who come from the poorest households tend to gain significant amounts of weight after the introduction of the government transfer payments. Additionally, we find some evidence that the height of children who grew up in the richest families increases due to the extra income transfers. Overall this leads to differential 
increases in BMI and risks of becoming obese depending on initial conditions. We show that these effects are not due to initial health conditions as proxied by birth weight or due to increases in own educational attainment.

Taken as a whole, our findings support the notion that household income affects adolescent's body mass index in very different ways depending upon where the household stands in the income distribution. This has significant implications for the design of policies intended to address the continuing adolescent and young adult obesity epidemic in the US. 
References:

Akee, Randall and William Copeland, Gordon Keeler, Adrian Angold and E. Jane Costello. 2010. “Parent’s Incomes and Children’s Outcomes: A Quasi-Experiment with Casinos on American Indian Reservations,” American Economics Journal: Applied Economics, Volume 2, No. 1, January, pp. 86-115.

Anderson, Patricia, Kristin Butcher, and Diane Schanzenbach, 2007 “Childhood Disadvantage and Obesity: Is Nurture Trumping Nature?” NBER Working Paper No. W13479, October 2007

Anderson, Sarah E. and Robert C. Whitaker "Prevalence of Obesity Among US Preschool Children in Different Racial and Ethnic Groups” Archives of Pediatric Adolescence Med. 2009;163(4):344-348.

Behrman, Jere (1997). “Intrahousehold Distribution and the Family,” In Mark Rosenzweig and Oded Stark, eds., Handbook of Population and Family Economics. Amsterdam: NorthHolland.

Behrman, Jere and Anil Deolalikar. 1987. "Will developing country nutrition improve with income? A case study for rural south India.” Journal of Political Economy. 95(4): 492-506.

Cawley J. 2004. The impact of obesity on wages. Journal of Human Resources 39: 451-474

Cawley, J., Moran, J., \& Simon, K. (In press) “The Impact of Income on the Weight of Elderly Americans.” Health Economics. 
Chang, Virginia and Diane Lauderdale. 2005. “Income Disparities in Body Mass Index and Obesity in the United States, 1971-2002.” Archives of Internal Medicine. V. 165: 2122-2128. Chiappori, Pierre-Andre. 1992. “Collective Labor Supply and Welfare.” Journal of Political Economy, 100(3): 437ñ67.

Currie, Janet, Stefano Della Vigna, Enrico Moretti, and Vikram Pathania "The Effect of Fast Food Restaurants on Obesity and Weight Gain," forthcoming American Economic Journals: $\underline{\text { Economic Policy }}$

Cutler DM, Glaeser EL, Shapiro JM. 2003. Why have Americans become more obese? Journal of Economic Perspectives 17(3): 93-118.

Danielzik, S, M Czerwinski-Mast, K Langnäse, B Dilba and M J Müller. 2004. “Parental overweight, socioeconomic status and high birth weight are the major determinants of overweight and obesity in 5-7 y-old children: baseline data of the Kiel Obesity Prevention Study” International Journal of Obesity, Vol. 28, 1494-1502

Duflo, Esther. 2003. “Grandmothers and Granddaughters: Old Age Pension and IntraHousehold Allocation in South Africa.” World Bank Economic Review, 17(1): 1ñ25.

Duflo, Esther and Udry, Christopher R. 2003. “Intrahousehold Resource Allocation in Cote d'Ivoire: Social Norms, Separate Accounts and Consumption Choices.” Bureau for Research in Economic Analysis of Development Working Paper 016.

Edmonds, Eric. 2008 "Child Labor”. Handbook of Development Economics 
Lakdawalla Darius \& Tomas Philipson, 2002. "The Growth of Obesity and Technological Change: A Theoretical and Empirical Examination," NBER Working Paper 8946

Hamermesh, Daniel and J. Biddle. 1994. "Beauty and the Labor Market." American Economic Review, December.

Hallliday, Timothy and S. Kwak. 2009. “Weight Gain in Adolescents and their Peers”, Economics and Human Biology, 7(2): 181-190.

Hoddinott, John and Emmanuel Skoufias. 2004. “The impact of PROGRESA on food consumption”, Economic Development and Cultural Change, 53 (1): 37-61.

Inas Rashad \& Michael Grossman \& Shin-Yi Chou, 2006. "The Super Size of America: An Economic Estimation of Body Mass Index and Obesity in Adults," Eastern Economic Journal, Eastern Economic Association, vol. 32(1), pages 133-148, Winter.

Komlos John, Ariane Breitfelder and Marco Sunder. 2008. “The Transition to Post-industrial BMI Values among US Children” NBER WP 13898

Lundberg, Shelly and Pollak, Robert A. 1996. "Bargaining and Distribution in Marriage.” Journal of Economic Perspectives, 10(4): 139 ñ58.

Lundberg, S., R. Pollak and T. Wales (1997). “Do Husbands and Wives Pool Their Resources: Evidence from the U.K Child Benefit.” JHR 32.3, Summer: 463-480. 
Malrid, S, M. Bondestam, R. Bergstr, S. Ehnberg, A. Hollsing, K. Albertsson-Wikland' 2004. "Prevalence trends of obesity and overweight among 10-year-old children in western


12 December , pages $1588-1595$.

Mazzocco, Maurizio. 2007. "Household Intertemporal Behaviour: A Collective

Characterization and a Test of Commitment." Review of Economic Studies, 74(3): 857-895.

Mocan, Naci and Erdal Tekin " Obesity, Self-esteem and Wages," forthcoming in Economic Aspects of Obesity, Michael Grossman and Naci Mocan (eds.) NBER/University of Chicago Press

Nguyen, VT, DE Larson, RK Johnson and MI Goran "Fat intake and adiposity in children of lean and obese parents“ American Journal of Clinical Nutrition, Vol 63, 507-513

Ogden, Cynthia L. and Margaret D. Carroll, Lester R. Curtin, Molly M. Lamb and Katherine M. Flegal. 2010. "Prevalence of High Body Mass Index in US Children and Adolescents, 2007-2008” Journal of the American Medical Association. Vol. 303 No. 3, January 20.

Reed, A.J., Levedahl, J.W., Hallahan, C.(2005) “The generalized composite commodity theorem and food demand estimation” . American Journal of Agricultural Economics 87, 2837

Richards, Timothy and Paul Patterson. 2006. “Native American Obesity: An Economic Model of the 'Thrifty Gene’ Theory”. American Journal of Agricultural Economics. Volme 88 No. 3, August, p 542-560. 
Rogol Alan D , Pamela A Clark, and James N Roemmich (2000) “Growth and pubertal development in children and adolescents: effects of diet and physical activity" Am J Clin Nutr 2000;72(suppl):521S-8S

Schmeiser, Maximilian (2009) “Expanding Wallets and Waistlines: The Impact of Family Income on the BMI of Women and Men Eligible for the Earned Income Tax Credit” Health Economics, 18, 1277-1294

Silventoinen, Karri. 2003. “Determinants of Variation in Adult Body Height.” J.Biosocial Sci. 35 (April): 263-85.

Smith, Trenton and Christiana Stoddard and Michael Barnes. 2007. "Why the Poor Get Fat: Weight Gain and Economic Insecurity.” Washington State University School of Economic Sciences Working Paper Series. WP 2007-16.

Souleles, Nicholas S. (1999) “The Response of Household Consumption to Income Tax Refunds” The American Economic Review, Vol. 89, No. 4 (Sep., 1999), pp. 947-958

Steckel, R.H. 1987. "Growth depression and recovery: the remarkable case of American Slaves.” Annals of Human Biology, 14, 111-132.

Steckel, R.H. (2008), Biological measures of the standard of living, Journal of Economic Perspectives, 22, 129-152. 
Thomas, Duncan. 1990. “Intra-household Resource Allocation: An Inferential Approach.” Journal of Human Resources, 25(4): 635ñ64.

Thomas, Duncan. 1994. “Like Father, Like Son or Like Mother, Like Daughter: Parental Education and Child Height.” Journal of Human Resources, 29(4): 950 No 989.

Udry, Christopher R. 1996. “Gender, Agricultural Production and the Theory of the Household.” Journal of Political Economy, 104(5): 1010ñ46.

Van Den Berg, Gerard, Petter Lundborg, Paul Nystedt and Dan-Olof Rooth (2009) “Critical Periods During Childhood and Adolescence: A Study of Adult Height Among Immigrant Siblings “ IZA DP No. 4140, April 2009 
Tables and Figures

Table 1: Means and Standard Deviations of Main Outcomes and Control Variables

\begin{tabular}{|c|c|c|c|c|c|c|}
\hline & \multicolumn{3}{|c|}{ Non-Indians } & \multicolumn{3}{|c|}{ American Indian } \\
\hline & Obs. & Mean & St. Dev. & Obs. & Mean & St. Dev. \\
\hline Obese & 6703 & 0.207 & 0.405 & 2339 & 0.447 & 0.497 \\
\hline Overweight (inclusive of obese) & 6703 & 0.395 & 0.489 & 2339 & 0.654 & 0.476 \\
\hline Body Mass Index (BMI) & 6728 & 23.344 & 5.978 & 2341 & 27.320 & 7.774 \\
\hline Weight in kgs & 6728 & 62.389 & 21.920 & 2341 & 72.772 & 26.140 \\
\hline Height in $\mathrm{cm}$ & 6728 & 161.549 & 14.144 & 2341 & 161.571 & 12.714 \\
\hline Age & 6705 & 15.608 & 4.709 & 2339 & 15.779 & 4.605 \\
\hline Sex $(1=$ male $)$ & 6728 & 0.545 & 0.498 & 2341 & 0.522 & 0.500 \\
\hline Number of American Indian & & & & & & \\
\hline Parents & 6728 & 0.021 & 0.156 & 2341 & 1.223 & 0.619 \\
\hline $\begin{array}{l}\text { Mother with high school } \\
\text { education }\end{array}$ & 6728 & 0.290 & 0.454 & 2341 & 0.342 & 0.474 \\
\hline Mother with college education & 6728 & 0.516 & 0.500 & 2341 & 0.338 & 0.473 \\
\hline $\begin{array}{l}\text { Mother participates in the labor } \\
\text { force }\end{array}$ & 6116 & 0.853 & 0.291 & 1996 & 0.854 & 0.294 \\
\hline $\begin{array}{l}\text { Average pre-casino household } \\
\text { income }\end{array}$ & 6680 & 6.411 & 3.416 & 2312 & 4.111 & 2.841 \\
\hline Low birth weight $[<2500$ grams] & 6728 & 0.065 & 0.246 & 2341 & 0.046 & 0.210 \\
\hline 2500 gr $<$ Birth weight $<4500$ gr & 6728 & 0.862 & 0.345 & 2341 & 0.878 & 0.327 \\
\hline Birth weight $>4500$ gr & 6728 & 0.073 & 0.261 & 2341 & 0.076 & 0.264 \\
\hline High school graduate & 6107 & 0.916 & 0.277 & 2134 & 0.885 & 0.319 \\
\hline
\end{tabular}


Table 2: Marginal Effect of Casino Transfers on Obesity and Overw eight Status at Ages 19 and 21; Probit Regressions

\begin{tabular}{|c|c|c|c|c|c|c|}
\hline \multirow[b]{2}{*}{ VARIABLES } & \multicolumn{3}{|c|}{19 Year-Olds } & \multicolumn{3}{|c|}{21 Year-Olds } \\
\hline & $\begin{array}{c}\text { (1) } \\
\text { Obese }\end{array}$ & $\begin{array}{c}\text { (2) } \\
\text { Obese }\end{array}$ & $\begin{array}{c}\text { (3) } \\
\text { Overw eight }\end{array}$ & $\begin{array}{c}\text { (4) } \\
\text { Obese } \\
\end{array}$ & $\begin{array}{c}(5) \\
\text { Obese } \\
\end{array}$ & $\begin{array}{c}\text { (๑) } \\
\text { Overw eight }\end{array}$ \\
\hline Age Cohort $1 \times$ Number of & & $-0.0284 * *$ & $-0.0890 * * *$ & & $-0.0444 * * *$ & -0.0384 \\
\hline AI Parents x Average $\mathrm{HH}$ & & $(0.0125)$ & $(0.0250)$ & & $(0.0167)$ & (0.0388) \\
\hline Age Cohort $2 \times$ Number of & & 0.00513 & 0,0000 & & 0.00295 & 0.0530 \\
\hline AI Parents x Average $\mathrm{HH}$ & & $(0.0117)$ & $(0.0217)$ & & $(0.0169)$ & $(0.0364)$ \\
\hline Age Cohort $1 \times$ Number of & -0.0244 & 0.119 & $0.491 * * *$ & -0.0525 & $0.175^{*}$ & 0.178 \\
\hline American Indian Parents & $(0.0411)$ & $(0.0755)$ & $(0.167)$ & $(0.0513)$ & $(0.102)$ & (0.194) \\
\hline Age Cohort $2 \times$ Number of & 0.0100 & -0.0225 & 0.0694 & 0.0157 & -0.0126 & -0.00831 \\
\hline American Indian Parents & $(0.0420)$ & (0.0753) & $(0.128)$ & $(0.0543)$ & $(0.104)$ & $(0.184)$ \\
\hline Age Cohort $1 \times$ Average & & 0.0125 & $0.0380 * *$ & & $0.0258 *$ & $0.0472 * *$ \\
\hline HH Income & & (0.0103) & $(0.0158)$ & & $(0.0138)$ & $(0.0198)$ \\
\hline Age Cohort $2 \times$ Average & & -0.0121 & 0.00741 & & -0.00725 & 0.0247 \\
\hline $\mathrm{HH}$ Income & & (0.0102) & $(0.0150)$ & & $(0.0142)$ & $(0.0209)$ \\
\hline AI Parents and Average & & 0.00450 & -0.00799 & & 0.00147 & -0.00921 \\
\hline HH Income & & $(0.00865)$ & $(0.0149)$ & & $(0.0123)$ & $(0.0222)$ \\
\hline \multirow[t]{2}{*}{ Average $\mathrm{HH}$ Income } & $-0.0120 * * *$ & -0.0118 & $-0.0253 * *$ & -0.00818 & -0.0166 & -0.0206 \\
\hline & $(0.00437)$ & $(0.00775)$ & (0.0113) & $(0.00564)$ & $(0.0111)$ & $(0.0144)$ \\
\hline \multirow[t]{2}{*}{ Age Cohort 1 (13 yo) } & 0.0380 & -0.0422 & -0.162 & 0.0596 & -0.102 & -0.189 \\
\hline & $(0.0470)$ & (0.0708) & (0.100) & $(0.0540)$ & $(0.0920)$ & $(0.141)$ \\
\hline \multirow[t]{2}{*}{ Age Cohort 2 (15 yo) } & -0.0102 & 0.0657 & -0.107 & 0.0189 & 0.0743 & -0.136 \\
\hline & (0.0428) & $(0.0890)$ & $(0.118)$ & $(0.0570)$ & $(0.120)$ & (0.158) \\
\hline \multirow[t]{2}{*}{ Number of AI Parents } & -0.0379 & -0.0488 & 0.0193 & $-0.0952 *$ & -0.0673 & 0.00686 \\
\hline & (0.0379) & $(0.0614)$ & $(0.112)$ & $(0.0498)$ & $(0.0824)$ & $(0.143)$ \\
\hline \multirow[t]{2}{*}{ American Indian race } & $0.331 * * *$ & $0.283 * * *$ & $0.223^{*}$ & $0.424 * * *$ & $0.311 * * *$ & $0.234 * * *$ \\
\hline & $(0.0803)$ & $(0.0795)$ & $(0.115)$ & $(0.0842)$ & $(0.0797)$ & $(0.0904)$ \\
\hline \multirow[t]{2}{*}{ Sex } & 0.0145 & 0.0130 & 0.0390 & 0.0508 & 0.0492 & 0.0816 \\
\hline & $(0.0329)$ & $(0.0317)$ & $(0.0474)$ & $(0.0399)$ & $(0.0395)$ & $(0.0554)$ \\
\hline Mother has a High School & 0.00266 & -0.00236 & 0.0670 & -0.00105 & -0.00869 & 0.0611 \\
\hline Diploma & $(0.0574)$ & $(0.0553)$ & $(0.0908)$ & $(0.0692)$ & $(0.0670)$ & (0.101) \\
\hline Mother has Some College & -0.0346 & -0.0451 & -0.0213 & $-0.135 *$ & $-0.140 *$ & -0.103 \\
\hline or More & $(0.0590)$ & $(0.0590)$ & $(0.0850)$ & $(0.0770)$ & $(0.0777)$ & $(0.0980)$ \\
\hline Average Labor Force & -0.0285 & -0.0315 & -0.0531 & 0.0693 & 0.0643 & -0.0423 \\
\hline Participation of Mother & $(0.0544)$ & $(0.0521)$ & $(0.0773)$ & $(0.0697)$ & $(0.0660)$ & $(0.0921)$ \\
\hline Observations & & & & & & \\
\hline Observations & 920 & 920 & 920 & 912 & 912 & 912 \\
\hline
\end{tabular}

Robust standard errors in parentheses

$* * * p<0.01, * * p<0.05, * p<0.1$ 
Table 3: Effect of Casino Transfers on BMI; Individual Fixed-Effects Panel Regression

\begin{tabular}{|c|c|c|c|c|}
\hline VARIABLES & $\begin{array}{c}(1) \\
\text { BMI }\end{array}$ & $\begin{array}{c}(2) \\
\text { BMI }\end{array}$ & $\begin{array}{c}(3) \\
\text { BMI }\end{array}$ & $\begin{array}{c}(4) \\
\text { BMI }\end{array}$ \\
\hline Household Eligible for Casino & $1.120 * * *$ & -0.422 & $4.623 * * *$ & $3.102 * *$ \\
\hline Disbursement & $(0.271)$ & $(0.460)$ & $(1.313)$ & $(1.441)$ \\
\hline Age & $\begin{array}{l}0.617 * * * \\
(0.0365)\end{array}$ & $\begin{array}{l}0.618 * * * \\
(0.0365)\end{array}$ & $\begin{array}{l}0.612 * * * \\
(0.0360)\end{array}$ & $\begin{array}{l}0.614 * * * \\
(0.0367)\end{array}$ \\
\hline Interaction of Casino and Age & & & $\begin{array}{l}-0.269 * * * \\
(0.0880)\end{array}$ & $\begin{array}{l}-0.241 * * * \\
(0.0889)\end{array}$ \\
\hline Interaction of AI and Age & & & $\begin{array}{l}0.250 * * * \\
(0.0839)\end{array}$ & $\begin{array}{l}0.214 * * \\
(0.0841)\end{array}$ \\
\hline Labor Force Participation of the & $\begin{array}{c}0.0559 \\
(0.0549)\end{array}$ & $\begin{array}{l}0.0525 \\
(0.0550)\end{array}$ & $\begin{array}{l}0.0516 \\
(0.0548)\end{array}$ & $\begin{array}{c}0.0494 \\
(0.0551)\end{array}$ \\
\hline $\mathrm{N}$ Children in $\mathrm{HH}<6$ & $\begin{array}{l}-0.424^{* *} \\
(0.160)\end{array}$ & $\begin{array}{l}-0.429 * * * \\
(0.160)\end{array}$ & $\begin{array}{l}-0.426 * * \\
(0.167)\end{array}$ & $\begin{array}{c}-0.433 * * * \\
(0.167)\end{array}$ \\
\hline Casino $\mathrm{x}$ Lowest Average $\mathrm{HH}$ & & $1.726^{*}$ & & 1.332 \\
\hline Income Cat in First 3 Survey Waves & & (0.931) & & (0.920) \\
\hline Casino $x$ 2nd Average $\mathrm{HH}$ Income & & $1.798 * * *$ & & $1.436^{* *}$ \\
\hline Cat in First 3 Survey Waves & & $(0.638)$ & & $(0.607)$ \\
\hline Casino $\times$ 3rd Average $\mathrm{HH}$ Income & & $1.920 * * *$ & & $1.497 * *$ \\
\hline Cat in First 3 Survey Waves & & $(0.692)$ & & $(0.683)$ \\
\hline Casino $x 4$ th Average $\mathrm{HH}$ Income & & $1.728 *$ & & 1.405 \\
\hline Cat in First 3 Survey Waves & & (0.908) & & $(0.880)$ \\
\hline Casino $\times 5$ th Average $\mathrm{HH}$ Income & & 0.299 & & 0.0246 \\
\hline Cat in First 3 Survey Waves & & (0.753) & & $(0.780)$ \\
\hline $\begin{array}{l}\text { Casino } x \text { 6th and Higher Average } \mathrm{HH} \\
\text { Income Cat in First } 3 \text { Survey Waves }\end{array}$ & ref erence & ref erence & ref erence & ref erence \\
\hline Constant & $\begin{array}{c}14.79 * * * \\
(0.840\end{array}$ & $\begin{array}{c}14.83 * * * \\
(0.845)\end{array}$ & $\begin{array}{c}14.04 * * * \\
(0.862)\end{array}$ & $\begin{array}{c}14.17 * * * \\
(0.862)\end{array}$ \\
\hline $\begin{array}{l}\text { Observations } \\
\text { R-squared } \\
\text { N IDs } \\
\end{array}$ & $\begin{array}{r}5,008 \\
0.442 \\
+\quad 1216 \\
\end{array}$ & $\begin{array}{r}5,008 \\
0.444 \\
+\quad 1216 \\
\end{array}$ & $\begin{array}{r}5,008 \\
\quad 0.444 \\
\quad 1216\end{array}$ & $\begin{array}{r}5,008 \\
0.446 \\
-\quad 1216 \\
\end{array}$ \\
\hline
\end{tabular}

Robust standard errors in parentheses

$* * * p<0.01, * * p<0.05, * p<0.1$ 
Table 4: Effect of Casino Transfers on Weight in Kilograms; Individual Fixed-Effects Panel Regression

\begin{tabular}{|c|c|c|c|c|}
\hline VARIABLES & $\begin{array}{c}\text { (1) } \\
\text { Weight in } \\
\text { Kilograms }\end{array}$ & $\begin{array}{c}\text { (2) } \\
\text { Weight in } \\
\text { Kilograms }\end{array}$ & $\begin{array}{c}\text { (3) } \\
\text { Weight in } \\
\text { Kilograms }\end{array}$ & $\begin{array}{c}\text { (4) } \\
\text { Weight in } \\
\text { Kilograms }\end{array}$ \\
\hline Household Eligible for Casino & 3.769*** & -0.180 & $42.81 * * *$ & $39.95 * * *$ \\
\hline Age & $\begin{array}{c}3.076 * * * \\
(0.127)\end{array}$ & $\begin{array}{c}3.076 * * * \\
(0.127)\end{array}$ & $\begin{array}{l}3.131 * * * \\
(0.125)\end{array}$ & $\begin{array}{l}3.132 * * * \\
(0.125)\end{array}$ \\
\hline Interaction of Casino and Age & & & $\begin{array}{l}-2.572 * * * \\
(0.322)\end{array}$ & $\begin{array}{l}-2.524 * * * \\
(0.326)\end{array}$ \\
\hline Interaction of $\mathrm{AI}$ and Age & & & $\begin{array}{c}1.265^{* * *} \\
(0.347)\end{array}$ & $\begin{array}{c}1.211^{* * *} \\
(0.350)\end{array}$ \\
\hline Labor Force Participation of the & & & & \\
\hline Mother & $\begin{array}{c}0.207 \\
(0.208)\end{array}$ & $\begin{array}{l}0.199 \\
(0.207)\end{array}$ & $\begin{array}{l}0.151 \\
(0.204)\end{array}$ & $\begin{array}{c}0.149 \\
(0.203)\end{array}$ \\
\hline Number of Children in Household & & & & \\
\hline Less than 6 Years Old & $\begin{array}{l}-0.886 \\
(0.589)\end{array}$ & $\begin{array}{l}-0.915 \\
(0.594)\end{array}$ & $\begin{array}{c}-1.157^{* *} \\
(0.579)\end{array}$ & $\begin{array}{l}-1.179 * * \\
(0.583)\end{array}$ \\
\hline $\begin{array}{l}\text { Casino } x \text { Lowest Average HH Income } \\
\text { Cat in First } 3 \text { Survey Waves }\end{array}$ & & $\begin{array}{c}3.762 \\
(3.205)\end{array}$ & & $\begin{array}{c}1.876 \\
(3.033)\end{array}$ \\
\hline $\begin{array}{l}\text { Casino } x \text { 2nd Average HH Income } \\
\text { Cat in First } 3 \text { Survey Waves }\end{array}$ & & $\begin{array}{l}3977 \\
(2.664)\end{array}$ & & $\begin{array}{l}2771 \\
(2.382)\end{array}$ \\
\hline $\begin{array}{l}\text { Casino x 3rd Average HH Income } \\
\text { Cat in First } 3 \text { Survey Waves }\end{array}$ & & $\begin{array}{l}4.807^{*} \\
(2.601)\end{array}$ & & $\begin{array}{c}2.484 \\
(2.442)\end{array}$ \\
\hline $\begin{array}{l}\text { Casino } x 4 \text { th Average HH Income } \\
\text { Cat in First } 3 \text { Survey Waves }\end{array}$ & & $\begin{array}{l}8.955^{* *} \\
(4.268)\end{array}$ & & $\begin{array}{l}7.218^{*} \\
(3.870)\end{array}$ \\
\hline $\begin{array}{l}\text { Casino x } 5 \text { th Average HH Income Cat } \\
\text { in First } 3 \text { Survey Waves }\end{array}$ & & $\begin{array}{l}-0.585 \\
(3.435)\end{array}$ & & $\begin{array}{l}-1.879 \\
(3.124)\end{array}$ \\
\hline $\begin{array}{l}\text { Casino } x \text { 6th and Higher Average HH } \\
\text { Income Cat in First } 3 \text { Survey Waves }\end{array}$ & ref erence & ref erence & ref erence & ref erence \\
\hline Constant & $\begin{array}{c}14.69 * * * \\
(2.906)\end{array}$ & $\begin{array}{c}14.75^{* * *} \\
(2.900)\end{array}$ & $\begin{array}{c}9.453 * * * \\
(2.977)\end{array}$ & $\begin{array}{c}9.620 * * * \\
(2.986)\end{array}$ \\
\hline Observations & 5,008 & 5,008 & 5,008 & 5,008 \\
\hline R-squared & 0.626 & 0.628 & 0.638 & 0.640 \\
\hline Number of gsms & 1216 & 1216 & 1216 & 1216 \\
\hline
\end{tabular}

Robust standard errors in parentheses

$* * * \mathrm{p}<0.01, * * \mathrm{p}<0.05, * \mathrm{p}<0.1$ 
Table 5: Effect of Casino Transfers on Height in Centimeters; Individual Fixed-Effects Panel Regression

(1)

(2)

(3)

Height in Height in Height in Height in

VARIABLES

Centimeters Centimeters Centimeters Centimeters

\begin{tabular}{|c|c|c|c|c|}
\hline Household Eligible for Casino & 0.0271 & $3.819^{*}$ & $41.21 * * *$ & $46.66 * * *$ \\
\hline Disbursement & $(0.711)$ & $(2.194)$ & $(2.823)$ & $(3.530)$ \\
\hline \multirow[t]{2}{*}{ Age } & $2.072 * * *$ & $2.066 * * *$ & $2.190 * * *$ & $2.178 * * *$ \\
\hline & $(0.0970)$ & $(0.0973)$ & $(0.0946)$ & $(0.0945)$ \\
\hline \multirow[t]{2}{*}{ Interaction of Casino and Age } & & & $-2.493 * * *$ & $-2.584 * * *$ \\
\hline & & & $(0.215)$ & $(0.209)$ \\
\hline \multirow[t]{2}{*}{ Interaction of $\mathrm{AI}$ and Age } & & & $0.539 * *$ & $0.670 * * *$ \\
\hline & & & $(0.233)$ & $(0.222)$ \\
\hline \multirow[t]{2}{*}{ Labor Force Participation of the Mother } & 0.165 & 0.174 & 0.103 & 0.113 \\
\hline & $(0.149)$ & $(0.148)$ & $(0.143)$ & $(0.143)$ \\
\hline Number of Children in HH Less than 6 & 0.518 & 0.492 & 0.105 & 0.0980 \\
\hline Years Old & $(0.379)$ & $(0.381)$ & $(0.352)$ & $(0.352)$ \\
\hline Casino $x$ Lowest Average HH Income & & $-4.637^{*}$ & & $-5.334 * *$ \\
\hline Cat in First 3 Survey Waves & & $(2.630)$ & & $(2.447)$ \\
\hline Casino $x$ 2nd Average $\mathrm{HH}$ Income Cat & & $-5.592 * *$ & & $-6.108 * * *$ \\
\hline in First 3 Survey Waves & & $(2.419)$ & & $(2.207)$ \\
\hline Casino $x$ 3rd Average $\mathrm{HH}$ Income Cat & & -3.886 & & $-5.095 * *$ \\
\hline in First 3 Survey Waves & & $(2.433)$ & & $(2.260)$ \\
\hline Casino $x$ 4th Average $\mathrm{HH}$ Income Cat & & 0.912 & & 0.0415 \\
\hline in First 3 Survey Waves & & (3.398) & & (3.122) \\
\hline Casino $x$ th Average $\mathrm{HH}$ Income Cat in & & -4.154 & & $-4.604 *$ \\
\hline First 3 Survey Waves & & $(3.340)$ & & $(2.777)$ \\
\hline $\begin{array}{l}\text { Casino } x \text { 6th and Higher Average } \mathrm{HH} \\
\text { Income Cat in First } 3 \text { Survey Waves }\end{array}$ & ref erence & reference & reference & ref erence \\
\hline Constant & $129.2 * * *$ & $129.0 * * *$ & $125.3 * * *$ & $124.8 * * *$ \\
\hline & $(2.228)$ & $(2.228)$ & $(2.205)$ & $(2.197)$ \\
\hline Observations & 5,008 & 5,008 & 5,008 & 5,008 \\
\hline -squared & 0.552 & 0.556 & 0.590 & 0.593 \\
\hline number of IDs & 1216 & $\quad 1216$ & 1216 & $\quad 1216$ \\
\hline
\end{tabular}

Robust standard errors in parentheses

$* * * p<0.01, * * p<0.05, * p<0.1$ 
Table 6: Additional Body Mass Measures: Proability of being Obese, Overweight or Gaining Weight in the past 3 months

(1)

(2)
(3)

in the Last 3

\begin{tabular}{|c|c|c|c|}
\hline VARIABLES & Obese & Overweight & months \\
\hline Household Eligible for Casino & -0.0688 & -0.0679 & -0.0584 \\
\hline Disbursement & $(0.0602)$ & $(0.0752)$ & $(0.0583)$ \\
\hline Age & $\begin{array}{l}0.000393 \\
(0.00352)\end{array}$ & $\begin{array}{l}0.0130 * * * \\
(0.00376)\end{array}$ & $\begin{array}{c}0.00341 \\
(0.00275)\end{array}$ \\
\hline Labor Force Participation of the & 0.00416 & 0.00394 & 0.00 \\
\hline Mother & $(0.00492)$ & $(0.00595)$ & $(0.00470)$ \\
\hline $\begin{array}{l}\text { Number of Children in } \\
\text { Household Less than } 6 \text { Years }\end{array}$ & -0.0196 & $-0.0255^{*}$ & 0.00382 \\
\hline Old & $(0.0135)$ & $(0.0136)$ & $(0.00890)$ \\
\hline $\begin{array}{l}\text { Casino x Lowest Average } \mathrm{HH} \\
\text { Income Cat in First } 3 \text { Survey }\end{array}$ & 0.0460 & 0.00597 & $0.130^{*}$ \\
\hline Waves & $(0.0980)$ & $(0.107)$ & $(0.0707)$ \\
\hline $\begin{array}{l}\text { Casino } \times 2 \text { nd Average } \mathrm{HH} \\
\text { Income Cat in First } 3 \text { Survey }\end{array}$ & $0.132 *$ & 0.0984 & 0.0825 \\
\hline Waves & $(0.0726)$ & $(0.0815)$ & $(0.0633)$ \\
\hline $\begin{array}{l}\text { Casino } \times 3 \text { rd Average } \mathrm{HH} \\
\text { Income Cat in First } 3 \text { Survey }\end{array}$ & 0.111 & 0.0523 & $0.143 * *$ \\
\hline Waves & $(0.0768)$ & $(0.0798)$ & $(0.0702)$ \\
\hline $\begin{array}{l}\text { Casino } x 4 \text { th Average HH } \\
\text { Income Cat in First } 3 \text { Survey }\end{array}$ & 0.114 & 0.0845 & 0.0673 \\
\hline $\begin{array}{l}\text { Waves } \\
\text { Casino } \times 5 \text { th Average } \mathrm{HH}\end{array}$ & $\begin{array}{c}(0.0860) \\
0.0569\end{array}$ & $\begin{array}{c}(0.0890) \\
0.109\end{array}$ & $\begin{array}{l}(0.0784) \\
0.133^{* *}\end{array}$ \\
\hline $\begin{array}{l}\text { Income Cat in First } 3 \text { Survey } \\
\text { Waves } \\
\text { Casino } x \text { 6th and Higher }\end{array}$ & $(0.0760)$ & $(0.104)$ & $(0.0666)$ \\
\hline $\begin{array}{l}\text { Average HH Income Cat in First } \\
3 \text { Survey Waves }\end{array}$ & reference & reference & ref erence \\
\hline Constant & $\begin{array}{l}0.296 * * * \\
(0.0849)\end{array}$ & $\begin{array}{l}0.403 * * * \\
(0.0813)\end{array}$ & $\begin{array}{c}0.0376 \\
(0.0666)\end{array}$ \\
\hline $\begin{array}{l}\text { Observations } \\
\text { R-squared } \\
\text { Number of gsms }\end{array}$ & $\begin{array}{r}5,007 \\
0.004 \\
1215 \\
\end{array}$ & $\begin{array}{r}5,007 \\
0.018 \\
\quad 1215\end{array}$ & $\begin{array}{l}4,992 \\
0.007 \\
1213 \\
\end{array}$ \\
\hline
\end{tabular}

Robust standard errors in parenth

$* * * p<0.01, * * p<0.05, * p<0.1$ 
Figure 1: BMI distribution among American Indian and non-American Indian children from the three survey groups at age 19; the vertical line at 25 indicates the border for overweight BMI levels

Panel A

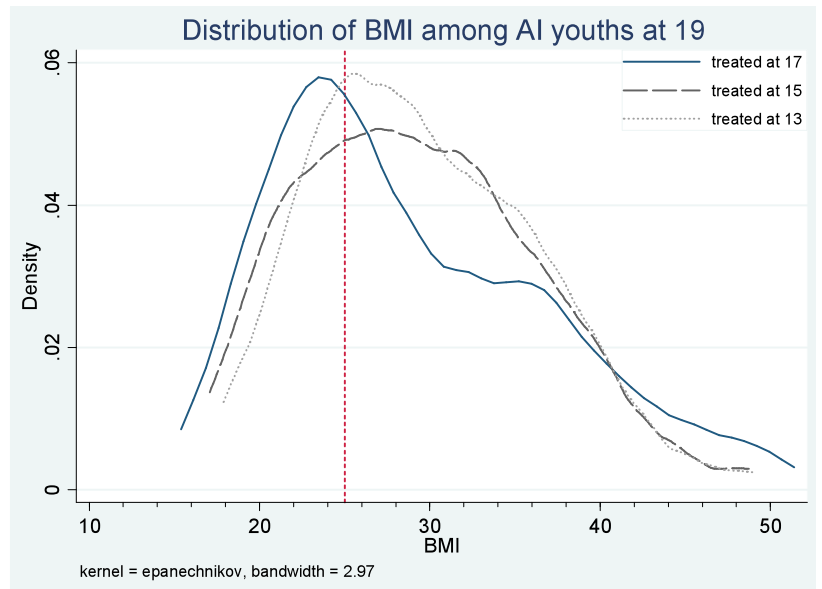

Panel B

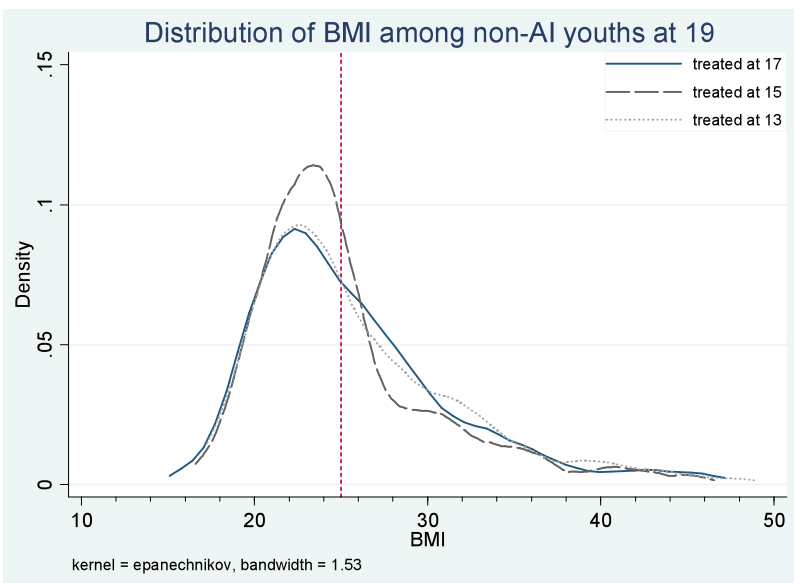

Figure 2: Plot of income* casino interaction effects on BMI. 95\% confidence intervals of fitted values in dashed grey lines 


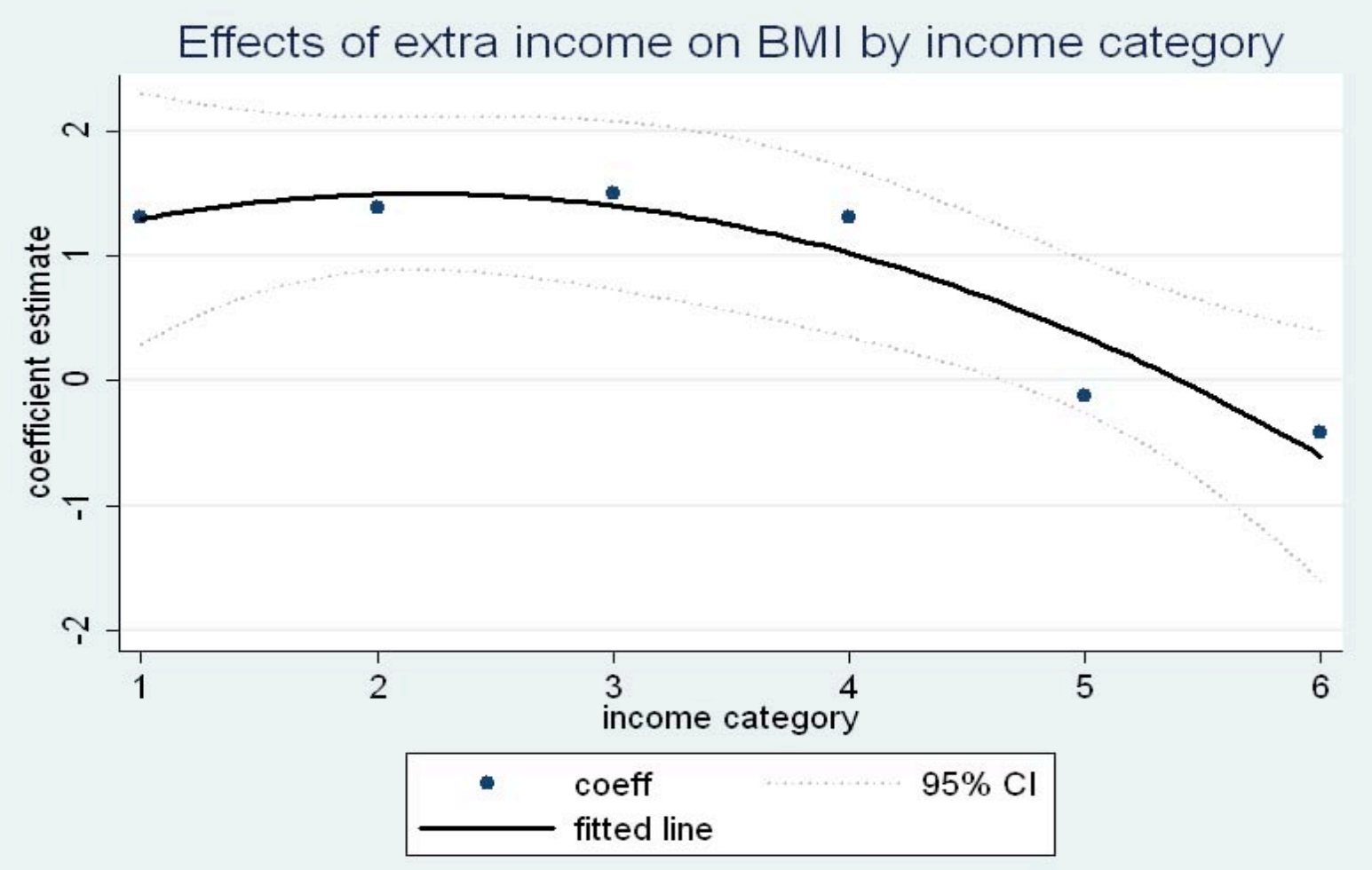

Figure 3: Plot of income*casino interaction effects on weight. 95\% confidence intervals of fitted values in dashed grey lines 


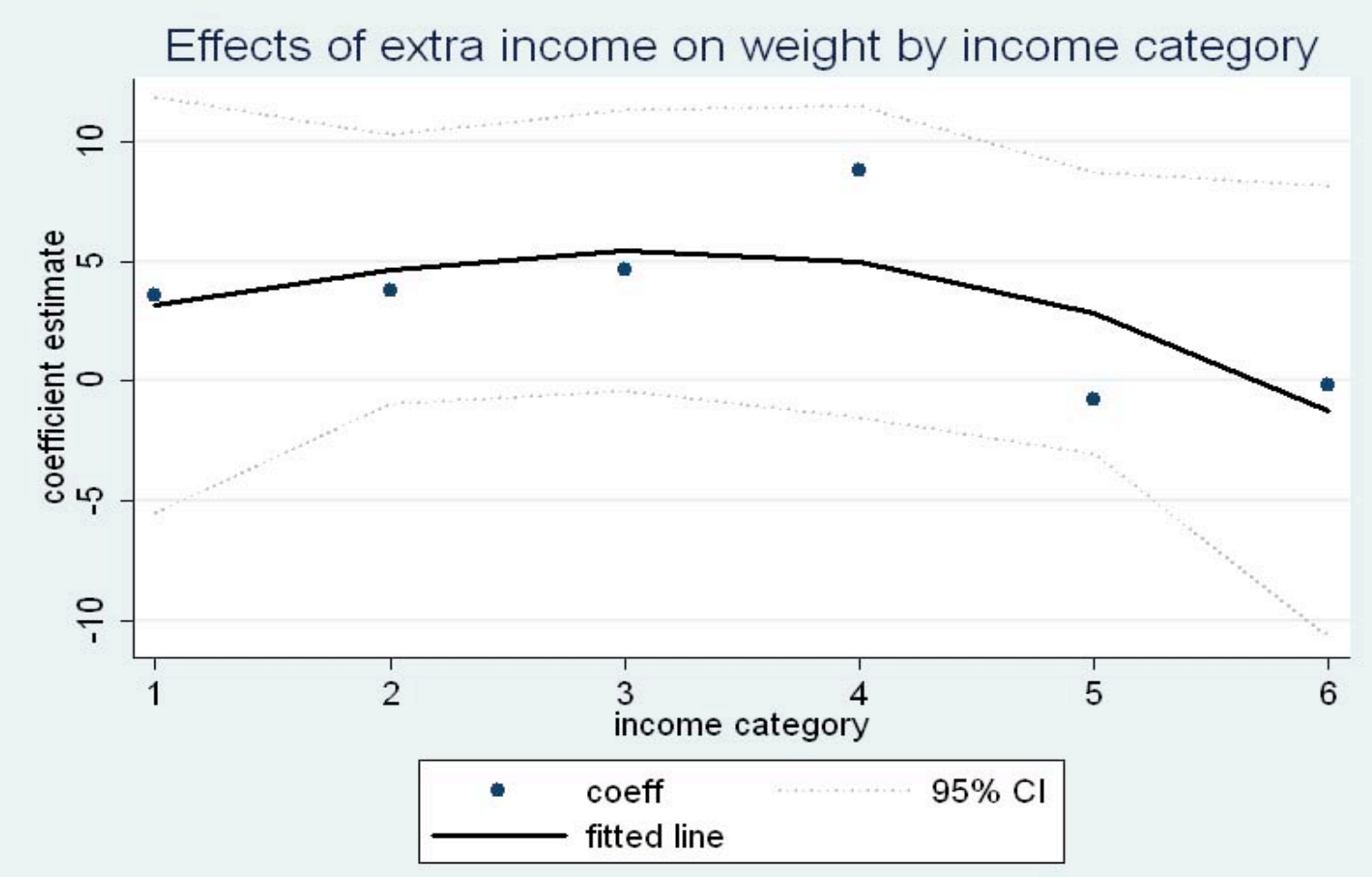

Figure 4: Plot of income* ${ }^{*}$ casino interaction effects on height. 95\% confidence intervals of $\begin{array}{lllll}\text { fitted } & \text { values } & \text { grey } & \text { lines }\end{array}$

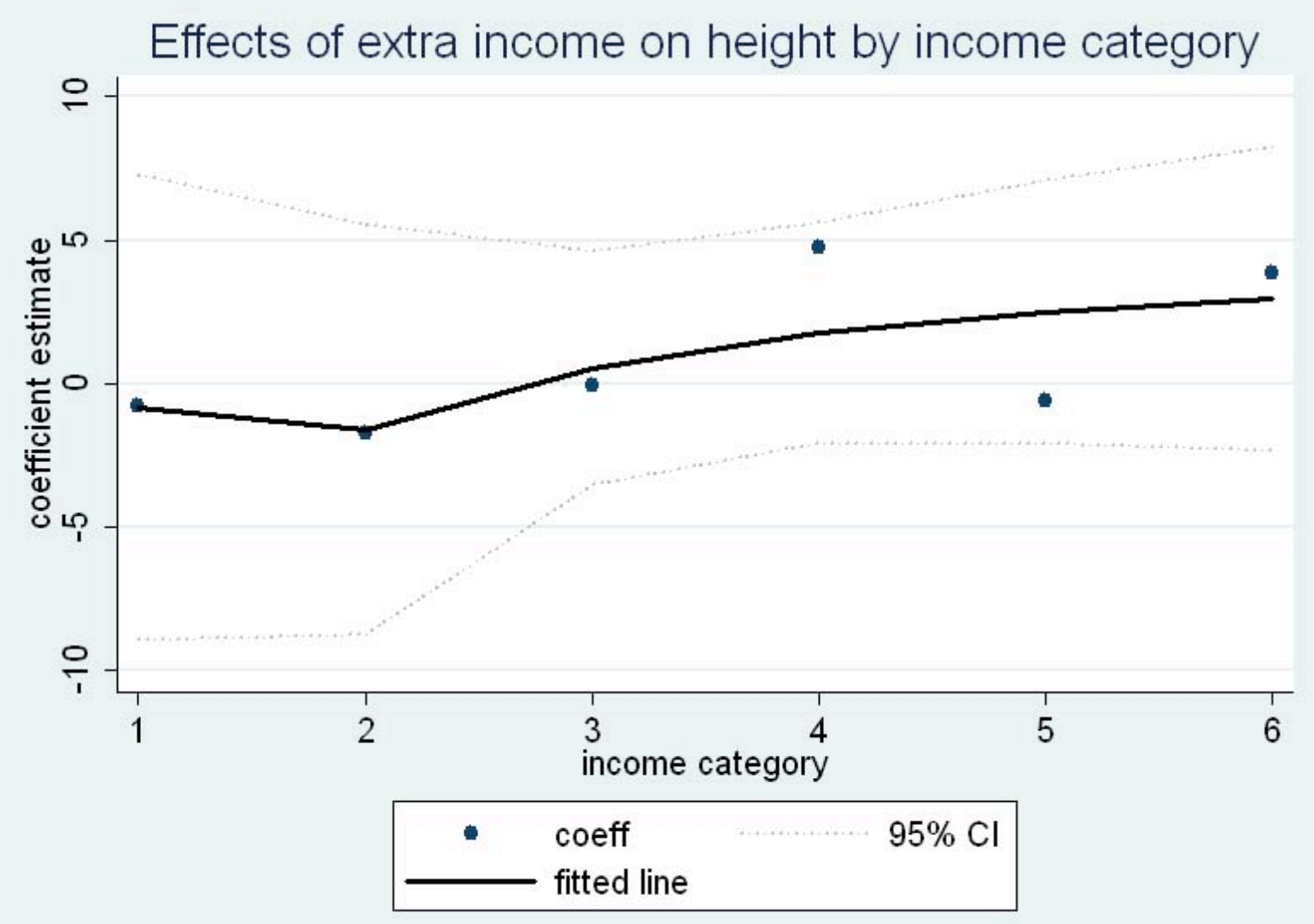




\section{Appendix}

Appendix Table 1: Effect of Cash Transfer on Child's Obesity at Ages 19 and 21 with Distance to Casino Interactions

(1) (2)

\begin{tabular}{lcc} 
VARIABLES & Obesity & Obesity \\
\hline Interaction 1: Age Cohort 1 x & 0.0241 & -0.125 \\
Number of AI Parents & $(0.0799)$ & $(0.0917)$ \\
& & \\
Interaction 2: Age Cohort 2 x & 0.0460 & -0.0223 \\
Number of AI Parents & $(0.0774)$ & $(0.0950)$ \\
& & \\
Interaction 1: Age Cohort 1 x & -0.0829 & 0.0709 \\
Number of AI Parents x Distance to & $(0.160)$ & $(0.225)$ \\
Casino & & \\
Interaction 2: Age Cohort 2 x & -0.160 & -0.180 \\
Number of AI Parents x Distance to & $(0.189)$ & $(0.274)$
\end{tabular}

Casino

Observations

856 853

Robust standard errors in parentheses

$* * * \mathrm{p}<0.01, * * \mathrm{p}<0.05, * \mathrm{p}<0.1$

Note: Includes all other covariates used in the main regressions as well as the distance measure and the distance measure interacted with the age cohort variables and distance interacted with the number of AI parents. Sample size decreases from previous crosssection regressions due to missing observations and covariates. 
Appendix Table 2: Placebo Test of the Effect of Cash Transfer on Child's Obesity at Age 13

\begin{tabular}{lc} 
VARIABLES & Obesity \\
\hline Interaction 1: Age Cohort 1 x & -0.0501 \\
Number of AI Parents & $(0.140)$ \\
& \\
Interaction 2: Age Cohort 2 x & 0.0264 \\
Number of AI Parents & $(0.0457)$
\end{tabular}

Robust standard errors in parentheses

$* * * \mathrm{p}<0.01, * * \mathrm{p}<0.05, * \mathrm{p}<0.1$

Note: Includes all of the variables from the main difference in difference regression in Table 2. Sample size is slightly reduced due to some missing observations at age 13 . 
Appendix Table 3: Difference in Difference Regression with Additional Controls at age 21; marginal effects from probit estimation method

\begin{tabular}{|c|c|c|c|c|}
\hline & $\begin{array}{c}(1) \\
\text { Obesity } \\
\end{array}$ & $\begin{array}{c}(2) \\
\text { Obesity }\end{array}$ & $\begin{array}{c}(3) \\
\text { Obesity }\end{array}$ & $\begin{array}{c}(4) \\
\text { Obesity } \\
\end{array}$ \\
\hline Age Cohort $1 \times$ Number of AI Parents $\mathrm{x}$ & $-0.176^{* * *}$ & $-0.179 * * *$ & $-0.196^{* * *}$ & $-0.159 * *$ \\
\hline Average HH Income & $(0.0656)$ & $(0.0650)$ & $(0.0696)$ & $(0.0670)$ \\
\hline Age Cohort $1 \times$ Number of AI Parents $\mathrm{x}$ & 0.0110 & 0.0108 & -0.0195 & 0.00151 \\
\hline Average HH Income & $(0.0675)$ & $(0.0671)$ & $(0.0725)$ & $(0.0695)$ \\
\hline Age Cohort $1 \times$ Number of American & $0.675^{*}$ & $0.698^{*}$ & $0.807^{*}$ & 0.666 \\
\hline Indian Parents & $(0.399)$ & $(0.403)$ & $(0.417)$ & $(0.413)$ \\
\hline Age Cohort $2 \times$ Number of American & -0.0418 & -0.0496 & 0.163 & 0.0830 \\
\hline Indian Parents & $(0.413)$ & $(0.415)$ & $(0.430)$ & $(0.424)$ \\
\hline HS graduate & $\begin{array}{c}0.151 \\
(0.180)\end{array}$ & & & \\
\hline Low birth weight & & $\begin{array}{l}-0.0942 \\
(0.345)\end{array}$ & & \\
\hline High birth weight & & $\begin{array}{c}0.274 \\
(0.325)\end{array}$ & & \\
\hline County Fixed Effects? & & & Yes & \\
\hline independent household income & & & & $\begin{array}{c}-0.0393 \\
(0.0499)\end{array}$ \\
\hline Constant & $\begin{array}{l}-0.651 \\
(0.497)\end{array}$ & $\begin{array}{c}-0.597 \\
(0.511)\end{array}$ & $\begin{array}{c}-0.448 \\
(0.580)\end{array}$ & $\begin{array}{c}-0.312 \\
(0.545)\end{array}$ \\
\hline Observations & 912 & 912 & 911 & 817 \\
\hline
\end{tabular}

Note: Includes all of the control variables from regression in Table 2 






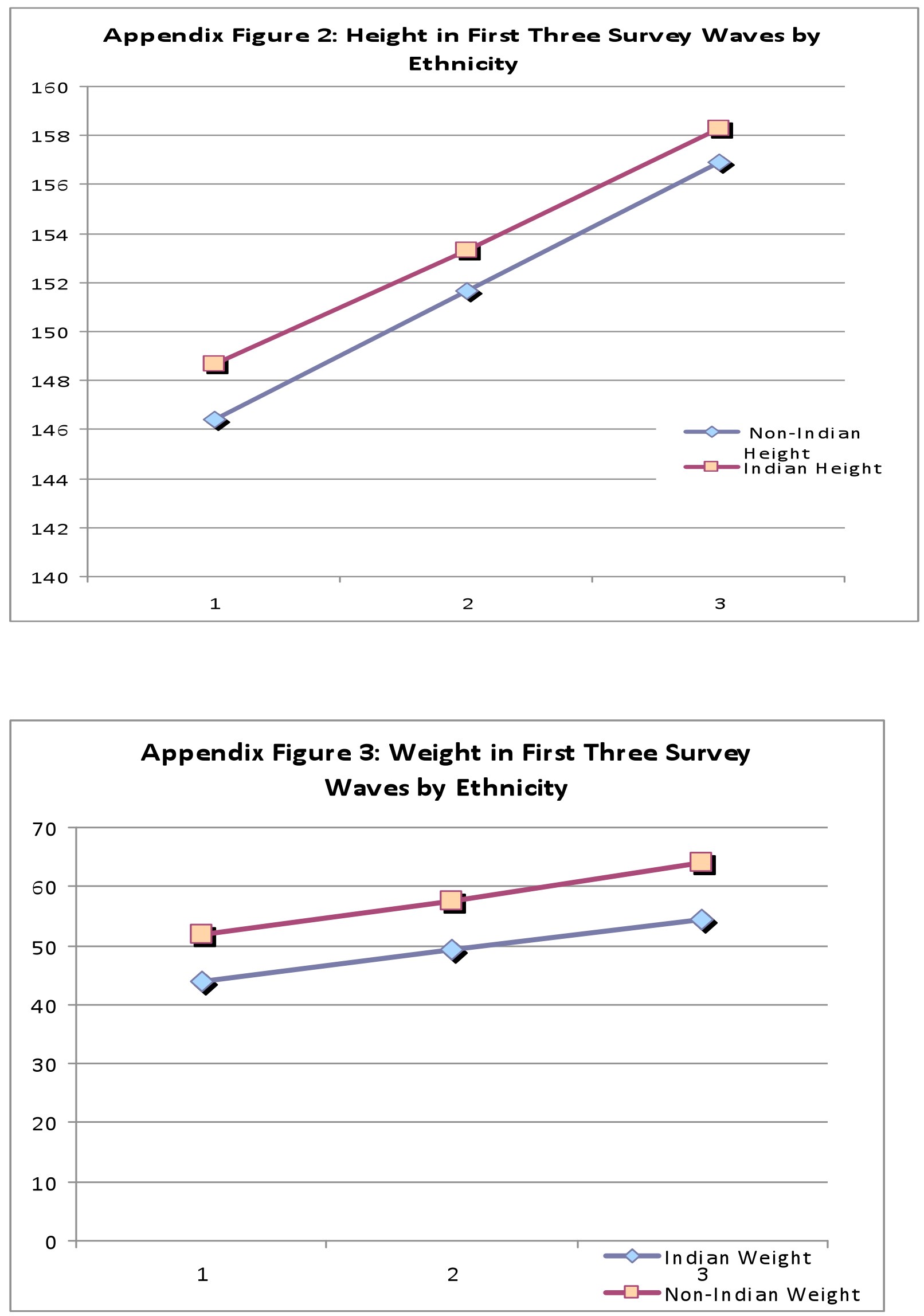